\title{
МОРОЗОСТІЙКІСТЬ І ЗИМОСТІЙКІСТЬ AILANTHUS ALTISSIMA (MILL.) В УМОВАХ ПРАВОБЕРЕЖНОГО ЛІСОСТЕПУ І СТЕПУ УКРАЇНИ
}

\begin{abstract}
Досліджено морозостійкість рослин Ailanthus altissima (Mill.) методом прямого проморожування пагонів для встановлення мінімальних критичних температур, що впливають на ріст і розвиток. Досліджено стан рослинного організму під дією низьких температур. Визначено індекс морозного пошкодження окремих частин пагона і бруньки. Наведено результати дослідження морозостійкості тканин пагонів і генеративних бруньок рослин A.altissima в умовах вимушеного спокою. Визначено зимостійкість і тривалість періоду спокою дерев A. altissima, які зростають у Національному дендрологічному парку "Софіївка" НАН України, Уманському НУС, Тальнівському парку Шувалова, у зелених насадженнях Умані та Уманського p-ну, парку ім. Петровського м. Первомайськ Миколаївської обл., міському парку м. Ватутіно Черкаської обл., дендрологічному парку Веселі Боковеньки Кіровоградської обл., смт Чечельник Вінницької обл. та в м. Саврань Одеської обл. Оцінено ступінь підмерзання частин і тканин пагона після проморожування. Оцінювання здійснено за шестибальною шкалою М. О. Соловйової та Д.В. Потаніна за побурінням тканин. Виявлено стійкість досліджених видів до комплексу несприятливих факторів в осінньо-зимовий період. Встановлено, що найнебезпечнішими для A. altissima є пізньовесняні приморозки, нестабільно теплі зими та холодні весни. З'ясовано, що для культури рослин досліджуваного виду важливо вжити заходів для сприяння захисту їх від ураження низькими температурами. Молоді рослини потрібно вкривати торфом, грунтом, листям, висаджувати в місцях, захищених від північних вітрів, а у дорослих дерев утеплювати прикореневі круги. Культуpa $A$. altissima в умовах Правобережного Лісостепу України є досить морозо- та зимостійкою.

Ключові слова: перезимівля; заморозки; дочасні морози; підмерзання; стійкість; вимушений спокій.
\end{abstract}

Вступ. Інтродукція та акліматизація рослин пов'язана 3 мінливістю пристосування їх до нових кліматичних умов існування. Успіх інтродукції у зонах із суворими кліматичними умовами залежить від стійкості рослин до несприятливих умов зимівлі. Як зазначає В.А. Нечитайло, стійкість рослин до комплексу несприятливих факторів в осінньо-зимовий період є одним 3 основних показників успішності інтродукції (Nechytailo \& Kucheriava, 2001; Musiienko, 2001). Зимостійкість та морозостійкість Ailanthus altissima не достатньо вивчені в умовах Правобережного Лісостепу і Степу України. В окремих джерелах наводять дані про зимостійкість виду, проте досліджень у цьому напрямі не здійснено (Kokhno et al., 2002). Розрізняють два види стійкості: морозостійкість і зимостійкість (Genkel \& Oknina, 1964). Під зимостійкістю розуміють весь комплекс пристосувань рослин до умов зовнішнього середовища в несприятливі для розвитку сезони року. Зимостійкість визначається ступенем відповідності між динамікою меж термостійкості органів і тканин рослин в осінньозимовий період і динамікою екстремальних режимів зміни температури. (Ahmatov, 1968; Burachinskij, 1967; Beskaravajnaja \& Bannaja, 1969).

Морозостійкість - це здатність рослин витримувати без пошкоджень низькі зимові температури. Тому однією з основних особливостей, які визначають значною мірою можливість культивування інтродукованих рослин у цих кліматичних зонах, є їхня морозостійкість. Саме морозостійкість значною мірою визначає зимостійкість рослин (Burachinskij, 1967; Gricenko, 1953). Як зазначає (Volf, 1917), морозостійкість у особин одного виду в однакових умовах може проявлятись по-різному. Він пояснює це явище тим, що одна рослина може бути вирощена 3 насіння південного походження, а інша - 3 більш суворих місць вирощування, і навіть іiі морозостійкість може бути індивідуальною особливістю. Несприятливими факторами для рослин є низькі мінусові температури повітря впродовж зимового періоду. Причиною загибелі та ушкодження рослин унаслідок дії морозів є замерзання води в клітинах, яке супроводжується механічним травмуванням мембран, дегідратацією та осмотичним шоком (Tumanov, 1967). Морозостійкість рослин характеризується зниженням активності фізіологічних процесів, своєчасним закінченням росту та визрівання пагонів, а також накопиченням у клітинах захисних речовин. До дії низьких температур найбільш чутливими є паренхімні тканини та квіткові бруньки, які прилягають до основи бруньки, де розміщена провідна система (Golodriga \& Sokolov, 1972).

Мета дослідження - встановлення мінімальних критичних температур для рослин Ailanthus altissima та ступеня їх ушкодження за допомогою методу прямого

Інформація про авторів:

Мамчур Валентина Василівна, аспірант. Email: mamcurvalentina@gmail.com

Цитування за ДСтУ: Мамчур В. В. Морозостійкість і зимостійкість Ailanthus Altissima (Мill.) в умовах Правобережного лісостепу і степу України. Науковий вісник НЛтУ України. 2017. Вип. 27(5). С. 21-24.

Citation APA: Mamchur, V. V. (2017). Frost resistance and winter hardiness of Ailanthus Altissima (Mill.) in Right-bank stepp and steppe of Ukraine. Scientific Bulletin of UNFU, 27(5), 21-24. https://doi.org/10.15421/40270503 
проморожування пагонів. Вивчення зимостійкості та морозостійкості Ailanthus altissima (Mill.) у Правобережному Лісостепу і Степу України.

Об'єкти та методика дослідження. Об'єктами досліджень були дерева айланта, які зростають у Національному дендрологічному парку "Софіївка" НАН України, Уманському НУС, Тальнівському парку Шувалова, в зелених насадженнях м. Умані та Уманського району, парку ім. Петровського м. Первомайськ Миколаївської обл., міському парку м. Ватутіно Черкаської обл., дендрологічному парку Веселі Боковеньки Кіровоградської обл., смт Чечельник Вінницької обл. та в м. Саврань Одеської обл. Зимостійкість Ailanthus altissimа в умовах Правобережного Лісостепу і Степу України оцінювали візуально за восьмибальною шкалою С. Я. Соколова (Sokolov, 1957):

1) рослина зимостійка (перезимувала без пошкоджень);

2) відмерзає верхівка річних пагонів;

3) відмерзають річні пагони;

4) відмерзають гілки останніх двох років;

5) відмерзають гілки останніх трьох років;

6) відмерзає стовбур до рівня снігового покриву;

7) відмерзає стовбур до кореневої шийки, проте рослина утворює поросль;

8) рослина гине від морозу.

Вивчення морозостійкості A. altissima проводилось згідно з методикою Н. А. Соловйової, (Soloveva, 1982), зимостійкості - за шкалою С. А. Соколова (Sokolov, 1957). Методика Н. А. Соловйової передбачає при польовому методі облік проводити взимку після морозів, навесні - перед розпусканням бруньок і в період інтенсивної вегетації рослин. Проморожування проводили в лабораторії фізіології Інституту садівництва УААН у холодильній камері "Frigera" 3 поступовим зниженням температури на $5{ }^{\circ} \mathrm{C}$ за температур $-25{ }^{\circ} \mathrm{C}$, $30{ }^{\circ} \mathrm{C}$. Дослідження виконували в трьох повторюваностях, що $\epsilon$ необхідним для проведення дисперсійного аналізу отриманих результатів (Potanin et al., 2005). Під час мікроскопічної оцінки однорічного приросту встановлювали рівень пошкодження окремих тканин або їх комплексів (флоеми, камбію, деревини і паренхімної тканини внутрішньої частини пагона) за візуальним побурінням на поперечному зрізі. Для підрахунку ушкоджень частини пагона множили бал пошкодження тканини на поправний коефіцієнт, що визначається значенням тканини для перебігу фізіологічних процесів (для флоеми -6 , камбію - 8, деревини -4 , паренхімної тканини внутрішньої частини пагона - 2) і отримували відсоток ушкодження окремої тканини та однорічного приросту (Potanin et al., 2005). Потенційну морозостійкість визначали під час анотомо-мікроскопічних досліджень після прямого проморожування пагонів. Пошкодження внутрішніх тканин однорічних приростів пагона визначали за шестибальною шкалою М. О. Соловйової (Soloveva, 1983), де:

- 1 - пошкоджень нема (0 \%);

- 2 - незначна зміна забарвлення, пошкоджено до $20 \%$ тканини;

- 3 - середнє пошкодження тканини (40 \%);

- 4 - спостерігається побуріння її межі з іншими тканинами $(60 \%)$;

- 5 - сильне пошкодження тканини, спостерігається побуріння, межі з іншими тканинами чорні (80 \%);

- 6 - повна загибель тканини, у деяких випадках її неможливо відокремити від іншої (100%).
Оцінку ступеня підмерзання частин і тканин після проморожування здійснювали за методикою М. О. Соловйової (Soloveva, 1982) та Д. В. Потаніна (Potanin et al., 2005) за побурінням тканин. Зимостійкість рослин визначали за методикою С. Я. Соколова (Sokolov, 1957).

Результати дослідження. Під час дослідження зимостійкості Ailanthus altissima, інтродукованих у Правобережному Лісостепу і Степу України, рослини проявили себе як відносно зимостійкі. Середні дані дослідження за 2014-2017 pр. наведено в табл. 1.

Табл. 1. Зимостійкість Ailanthus altissima (за 8-бальною шкалою С. Я. Соколова), інтродукованих у Правобережному Лісостепу і Степу України

\begin{tabular}{|c|c|c|c|c|}
\hline \multirow[b]{2}{*}{ Місце зростання } & \multicolumn{3}{|c|}{ Рік спостереження } & \multirow{2}{*}{$\begin{array}{c}\text { Се- } \\
\text { редній } \\
\text { бал }\end{array}$} \\
\hline & $\begin{array}{l}2014- \\
2015\end{array}$ & $\begin{array}{l}2015- \\
2016\end{array}$ & $\begin{array}{l}2016- \\
2017\end{array}$ & \\
\hline Уманський НУС & 3 & 3 & 3 & 3 \\
\hline $\begin{array}{l}\text { Національний дендрологічний } \\
\text { парк "Софіївка" }\end{array}$ & 3 & 3 & 2 & 2,6 \\
\hline Парк Шувалова м. Тальне & 3 & 3 & 4 & 3,3 \\
\hline $\begin{array}{l}\text { Зелені насадження м. Умань та } \\
\text { Уманського району }\end{array}$ & 3 & 4 & 3 & 3,3 \\
\hline $\begin{array}{l}\text { Дендрологічний парк Веселі Бо- } \\
\text { ковеньки Кіровоградської обл. }\end{array}$ & 2 & 3 & 2 & 2,3 \\
\hline $\begin{array}{l}\text { Парк ім. Петровського м. Перво- } \\
\text { майськ Миколаївської обл. }\end{array}$ & 1 & 1 & 2 & 1,3 \\
\hline смт Чечельник Вінницької обл. & 2 & 2 & 2 & 2 \\
\hline м. Саврань Одеської обл. & 1 & 1 & 2 & 1,3 \\
\hline $\begin{array}{l}\text { Міський парк м. Ватутіно Чер- } \\
\text { каської обл. }\end{array}$ & 3 & 3 & 3 & 3 \\
\hline $\begin{array}{l}\text { Дендрологічний парк Олексан- } \\
\text { дрія Київської обл. }\end{array}$ & 3 & 4 & 4 & 3,6 \\
\hline Куяльницький лиман м. Одеса & 1 & 1 & 1 & 1 \\
\hline
\end{tabular}

Навесні 2016 та 2017 рр. у Правобережному Лісостепу України спостерігалися пізньовесняні приморозки зі зниженням температури від $-2{ }^{\circ} \mathrm{C}$ до $-5^{\circ} \mathrm{C}$. Молоді новоутворенні пагони і листя дерев Ailanthus altissima, що зростали на відкритих ділянках, були повністю знищенні морозом, проте за кілька днів після приморозків рослини відновили свою вегетацію та набули властивого їм габітусу (рис.).

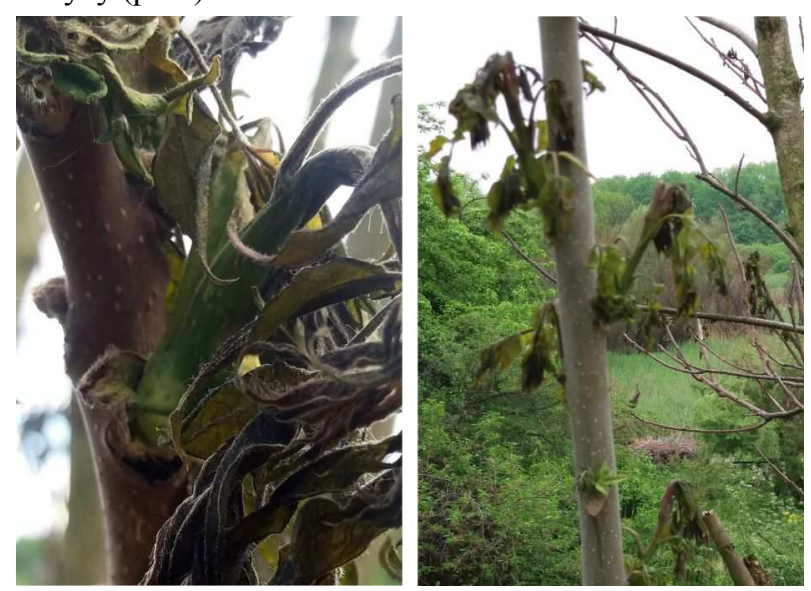

Рис. Рослини, пошкодженні морозом

За роки спостережень середній бал пошкодження у Правобережному Лісостепу України становив 3,3 та 2,6 бали відповідно. Рослини, які пошкоджувались морозами, зростали на відкритих ділянках. Пошкодження морозами верхівки річних пагонів та власне річних пагонів виявлено у всіх досліджуваних рослин. За віковим розподілом найменш морозостійкими були одно- та 
дворічні сіянці, у яких здерев'яніння пагонів становило 50-70\%, тобто їм властиве підмерзання 10-30\%. Підтвердженням цього $є$ погодні умови 2015-2016 рр., коли перша половина зими була безсніжною 3 досить низькими температурами. У Правобережному Степу Украіни (Одеська та Миколаївська обл.) середній бал пошкодження становив 1,0 та 1,3 бали відповідно.

Варто зазначити, що важливою обставиною для культури рослин досліджуваного виду є вжиття заходів захисту їх від ураження низькими температурами. Молоді рослини потрібно вкривати торфом, грунтом, листям, висаджувати в місцях, захищених від північних вітрів, а у дорослих дерев утеплювати прикореневі круги. Дослідженнями зимостійкості рослин Ailanthus altissima, інтродукованих у Правобережному Лісостепу та Степу України, встановлено, що ці показники у них досить різні і залежать від умов, віку рослин та місця зростання. Культура A. altissima в умовах Правобережного Лісостепу України цілком можлива.

Лабораторну оцінку морозостійкості проводили за методикою М. О. Соловйової (Soloveva, 1983), у модифікації В. В. Грохольського та О. І. Китаєва (Potanin et al., 2005). Зразки однорічних приростів відбирали в різних районах зростання айланту. За контроль було взято однорічні пагони, які зазнавали дії низьких температур в умовах, наближених до природних. Вивчення морозостійкості методом прямого проморожування базувалось на трьох етапах:

- 1 - відбір зразків для проморожування;

- 2 - безпосереднє проморожування;

- 3 - мікроскопічний аналіз ступеня ушкодження.

Цей метод успішно застосовують для визначення ступеня морозостійкості листяних деревних рослин (Golodriga \& Sokolov, 1972).

Після проморожування пагонів за температури $25^{\circ} \mathrm{C} \mathrm{i}-30{ }^{\circ} \mathrm{C}$ у період вимушеного спокою, зафіксовано певні закономірності пошкодження структур різних тканин. Дані досліджень наведено в табл. 2.

Табл. 2. Рівень пошкодження однорічних пагонів A. altissima після лабораторного проморожування (середні дані за температури $-25^{\circ} \mathrm{C} \mathrm{i}-30^{\circ} \mathrm{C}$ )

\begin{tabular}{|c|c|c|c|c|}
\hline \multirow{2}{*}{$\begin{array}{c}\text { Температу- } \\
\text { ра промо- } \\
\text { рожування, } \\
{ }^{\circ} \mathrm{C}\end{array}$} & \multicolumn{3}{|c|}{$\begin{array}{c}\text { Ступінь пошкодження } \\
\text { однорічного пагона }\end{array}$} & \multirow{2}{*}{$\begin{array}{c}\text { Загальний } \\
\text { ступінь } \\
\text { пошкодження, \% }\end{array}$} \\
\hline & $\begin{array}{c}\text { верхня } \\
\text { частина }\end{array}$ & $\begin{array}{l}\text { середня } \\
\text { частина }\end{array}$ & $\begin{array}{c}\text { під } \\
\text { брунь- } \\
\text { кою }\end{array}$ & \\
\hline \multicolumn{5}{|c|}{ Правобережний Лісостеп України } \\
\hline Контроль & 13,4 & 2,8 & 7,4 & 23,6 \\
\hline-25 & 19,2 & 18,2 & 23,6 & 61 \\
\hline-30 & 36,2 & 22,2 & 30,6 & 88,8 \\
\hline \multicolumn{5}{|c|}{ Правобережний Степ України } \\
\hline Контроль & 13,4 & 2,8 & 7,4 & 23,6 \\
\hline-25 & 16,2 & 15,2 & 19,5 & 50,9 \\
\hline-30 & 30,2 & 18,2 & 25,5 & 73,9 \\
\hline
\end{tabular}

Апікальна частина пагона під брунькою була найчутливіша до дії низьких температур майже в усіх дослідних об'єктів. Пошкодження однорічних пагонів дерев A. altissima, які зростають в умовах Правобережного Лісостепу, за дії температури $-25{ }^{\circ} \mathrm{C}$ до $-30{ }^{\circ} \mathrm{C}$ коливалось від 18,2\% у середині пагона до $36,2 \%$ біля верхівки та 30,6\% під брунькою. Загальний ступінь пошкодження становив 61 і 88,8 \%. Пошкодження однорічних пагонів A. altissima в умовах Правобережного Степу було значно меншим. У середині пагона цей показник становив 15,2 та 18,2\%, біля верхівки - від
16,2 до 30,2 \%, під брунькою - від 19,5 до 25,5 \%. Загальний ступінь пошкодження становив 50,9 і 73,9 \%.

Можна зробити висновок, що для айланта майже критичною $є$ температура $-30{ }^{\circ} \mathrm{C}$. Цей вид проявляє низьку стійкість до від'ємних температур. Найчутливішою до дії негативних температур виявилася верхня частина пагона, де найбільше пошкоджується флоема i камбій. Найнижчим рівнем стійкості до низьких температур відзначаються екземпляри, які зростають на відкритій місцевості та у вуличних посадках. В умовах лісопарку пошкодження було значно меншим.

\section{Висновки}

1. Найчутливішою частиною однорічних пагонів айланта найвищого $є$ флоема (деревина) і камбій верхівки. За умов проморожування $-30{ }^{\circ} \mathrm{C}$ зафіксовано $36,2 \%$ пошкоджень тканини.

2. Низькою морозостійкістю характеризуються молоді пагони дерев та однорічні сіянці. Спостереження, проведені навесні 2016 р., коли спостерігались пізньовесняні приморозки в період лінійного росту пагонів айланта найвищого, показали, що це є найнебезпечніші явища для нормального росту і розвитку.

3. Рослини айланта найвищого мають нижчу морозостійкість у молодому віці та на відкритих ділянках. Для більшості рослин зниження температури до $-30^{\circ} \mathrm{C}$ призводить до пошкодження 32-45 \% тканин пагона, що вважається верхньою межею стійкості деревних листяних рослин.

4. Встановлено, що рослини A. altissima в умовах Правобережного Степу більш зимостійкі, ніж ті, що зростають у Правобережному Лісостепу. Однією з відмінностей між Правобережним Лісостепом і Степом є сума активних температур, яка знаходиться у межах $2850^{\circ} \mathrm{C}$ для Правобережного Лісостепу та більше $3300{ }^{\circ} \mathrm{C}$ в Степу України. Відповідно збільшується тривалість вегетації A. altissima. У цілому природно-кліматичні умови Правобережного Лісостепу та Степу України є сприятливими для вирощування та впровадження в культуру A. altissima.

\section{Перелік використаних джерел}

Ahmatov, K. A. (1968). Metody opredelenija zimostojkosti drevesnyh rastenij. Frunze: Ilm, 40 p. [in Russian].

Beskaravajnaja, M. A., \& Bannaja, M. V. (1969). Rezultaty izuchenija morozoustojchivosti drevesnyh rastenij metodom promorazhivanija pobegov. Bjuleten Gosudarstvennogo Nikitskogo botanicheskogo sada, 1(8), 11-13. [in Russian].

Burachinskij, A. M. (1967). O nekotoryh osobennostjah vzaimosvjazi mezhdu periodom pokoja i zimostojkostju drevesnyh rastenij. In Puti i metody povyshenija zimostojkosti akklimatiziruemyh rastenij, (pp. 25-38). Kyiv: Nauk. dumka, 136 p. [in Russian].

Genkel, P. A., \& Oknina, E. Z. (1964). Sostojanie pokoja i morozoustojchivost plodovyh rastenij. Moscow: Nauka, 242 p. [in Russian].

Golodriga, P. Ia., \& Sokolov, A. V. (1972). Ekspress-metod i pribory dlja diagnostiki morozoustojchivosti rastenij. Fiziologija i biohimija kulturnyh rastenij, 4(6), 650-656. [in Russian].

Gricenko, M. F. (1953). Morozoustojchivost, zasuhoustojchivost i sezonnoe razvitie drevesnyh i kustarnikovyh porod v Donbase. Lesn. hoz-vo, 8, 41-48. [in Russian].

Kokhno, M. A., Parkhomenko, L. I., Zarubenko, A. U. et al. (2002). Dendroflora Ukrainy. Dykorosli y kultyvovani dereva i kushchi. Pokrytonasinni: dovidnyk. Part. I. Kyiv: Fitosotsiotsentr, 448 p. [in Ukrainian].

Kokhno, N. A., \& Kurdiuk, A. M. (1994). Teoreticheskie osnovy $i$ opyt introduktcii drevesnykh rastenii v Ukraine. Kyiv: Nauk. dumka, 184 p. [in Russian]. 
Kolesnychenko, O. M. (1973). Zalezhnist zymostiikosti introdukovanykh derevnykh roslyn vid periodu yikh rostu. Introduktsiia $i$ aklimatyzatsiia roslyn na Ukraini, 6, 136-141. [in Ukrainian].

Korovin, A. I. (1969). Ob otnoshenii rastenii k nizkim temperaturam i zamorozkam i puti povysheniia ikh kholodo- i zamorozkoustoichivosti. In Ustoichivost rastenii k nizkim polozhitelnym temperaturam i zamorozkam i puti ee povysheniia, (pp. 5-15). Moscow: Nauka, 136 p. [in Russian].

Musiienko, M. M. (2001). Fiziolohiia roslyn. Kyiv: Fitosotsiotsentr. 329 p. [in Ukrainian].

Nechytailo, V. A, \& Kucheriava, L. F. (2001). Botanika. Vyshchi roslyny. Kyiv: Fitosotsiotsentr, 432 p. [in Ukrainian].

Potanin, D. V., Groholskij, V. V., Kitaiev, O. I. et al. (2005). Viznachennja morozostijkosti plodovih porid laboratornim metodom prjamogo promorozhuvannja. Sadivnictvo, 56, 170-180. [in Ukrainian].
Sokolov, S. Ia. (1957). Sovremennoe sostoianie teorii aklimatizatcii i introduktcii rastenii. Introduktciia rastenii $i$ zelenoe stroitelstvo, 3, 26-30. Moscow-Leningrad: Akademizdat. [in Russian].

Soloveva, M. A. (1982). Metody opredeleniia zimostoikosti plodovykh i iagodnykh kultu. Leningrad: Gidrometeoizdat, 36 p. [in Russian].

Soloveva, M. A. (1983). Fiziologicheskie osnovy formirovaniia morozoustoichivosti plodovykh rastenii i zashhita ot zimnikh povrezhdenii. Selskokhoziaistvennaia biologiia, 7, 108-113. [in Russian].

Tumanov, I. I. (1967). Metody opredeleniia morozostoikosti rastenii. Moscow: Nauka, 88 p. [in Russian].

Vasilev, I. M. (1966). Rastenie $i$ holod. Moscow: Znanie, 32 p. [in Russian].

Volf, E. L. (1917). Nabliudeniia nad morozostoikostiu derevianistykh rastenii. Petrograd, 260 p. [in Russian].

Уманский национальный университет садоводства, г. Умань, Украина

\section{МОРОЗОУСТОЙЧИВОСТЬ И ЗИМОСТОЙКОСТЬ AILANTHUS ALTISSIMA (MILL.) В УСЛОВИЯХ ПРАВОБЕРЕЖНОЙ ЛЕСОСТЕПИ И СТЕПИ УКРАИНЫ}

Исследована морозоустойчивость растений Ailanthus altissima (Mill.) методом промораживания побегов для установления минимальных критических температур, влияющих на рост и развитие. Исследовано состояние растительного организма под действием низких температур. Определен индекс морозного повреждения отдельных частей побега и почки. Приведены результаты исследования морозоустойчивости тканей побегов и генеративных почек рода айлант в условиях вынужденного покоя. Определены зимостойкость и продолжительность периода покоя деревьев Ailanthus altissima, которые растут в Национальном дендрологическом парке "Софиевка" НАН Украины, Уманском НУС, парке Шувалова г. Тальное, в зеленых насаждениях Умани и Уманского р-на, парке им. Петровского г. Первомайск Николаевской обл., городском парке г. Ватутино Черкасской обл., дендрологическом парке Веселые Боковеньки Кировоградской обл., пгт Чечельник Винницкой обл. и в г. Саврань Одесской обл. Оценена степень подмерзания частей и тканей побега после промораживания. Оценку проводили по шестибалльной шкале Н. А. Соловьевой и Д.В. Потанина по побурению тканей. Оценена устойчивость исследованных видов в комплексе неблагоприятных факторов в осенне-зимний период. Установлено, что наиболее опасными для A. altissiта являются поздневесенние заморозки, нестабильно теплые зимы, холодная весна. Следует отметить, что важным обстоятельством для культуры растений исследованного нами вида, является принятие мер для содействия защите их от поражения низкими температурами. Молодые растения необходимо укрывать торфом, землей, листьями, высаживать в местах, защищенных от северных ветров, а у взрослых деревьев утеплять прикорневые круги. Культура Ailanthus altissima в условиях Правобережной Лесостепи Украины вполне морозо- и зимостойкая.

Ключевые слова: перезимовка; заморозки; досрочные морозы; подмерзание; устойчивость; вынужденный покой.

V. V. Mamchur

Uman National University of Horticulture, Uman, Ukraine

\section{FROST RESISTANCE AND WINTER HARDINESS OF AILANTHUS ALTISSIMA (MILL.) IN RIGHT-BANK STEPP AND STEPPE OF UKRAINE}

The success of introductions in areas with severe climatic conditions depends on the resistance of plants to adverse winter conditions. Therefore the study aims at investigating frost resistance of Ailanthus altissima (Mill.) in laboratory by direct freezing of shoots to establish minimum critical temperature that affect growth and development. In the course of the study the index of frost damage to individual parts of shoots and buds was determined. The research results revealed frost fabric shoots and generative buds kind Ailanthus altissima (Mill.) in conditions of forced rest. The authors also studied hardiness and duration of rest of Ailanthus altissima (Mill.), growing in the National Arboretum "Sofiyivka", NAS of Ukraine, Uman city, Shuvalov Talne Park, Uman landscaping, Petrovsky park in Pervomaysk Mykolaiv region, and other. Winter hardiness of Ailanthus altissima in terms of Right-Bank Forest-Steppe Ukraine was evaluated visually using eight-point scale by S. Y. Sokolov (1957). During the research the plants proved to be relatively winter-hardy. During the years of observations damage GPA was 3.3 and 2.6 points respectively. Plants were damaged by frost, growing in open areas. Frost damage tops annual shoots and the actual annual shoots were met in all the studied species. By age distribution annual seedlings were less hardy. The analysis of hardiness of Ailanthus altissima within species showed that their performance is quite different. However Ailanthus altissima culture in terms of Right-Bank Forest Steppe of Ukraine is possible. The degree of freezing of parts and tissues shoot after freezing was assessed. Evaluation for tissues browning was carried out by six-point scale by M. O. Solovyov and D. Potanin. Damage to the annual shoots for actions to $-30{ }^{\circ} \mathrm{C}-25^{\circ} \mathrm{C}$ temperature ranged from $18.2 \%$ in the middle of the shoot to the top at $36.2 \%$ and $30.6 \%$ at the bud. The total extent of damage was 61 and $88.8 \%$ respectively. It can be concluded that almost critical temperature is $-30{ }^{\circ} \mathrm{C}$. In difficult conditions the growth of this type exhibits a low resistance to negative temperatures. Most sensitive to the action of low temperatures was the upper part of the shoot, where most damaged were phloem and cambium. Specimens growing in the open showed the lowest level of resistance to low temperatures. Damage to the park plants was much smaller. Studied species revealed resistance to the complex unfavorable in the autumn and winter. The most dangerous for A. altissima were unstable late spring frost and warm winters with cold spring. Thus, we should note that measures to promote Ailanthus altissima protection from damage by low temperatures are to be taken. Young plants should cover peat, soil, leaves, planted in a place sheltered from north winds, and the mature trees insulate radical circles. Ailanthus altissima in terms of Right-Bank Forest-Steppe Ukraine is quite frost and winter-hardy.

Keywords: wintering; frozen foods; early frosts; freezing; stability; forced rest. 